\title{
ICMI AND ITS ROLES IN THE DEVELOPMENT OF THE MIDDLE CLASS MUSLIM COMMUNITIES IN INDONESIA IN THE NEW ORDER ERA
}

\author{
Riki Rahman*; Faisal S. Hazis** \\ *, ** Universiti Kebangsaan Malaysia, Bangi, Malaysia \\ email: ricky84rahman@gmail.com
}

\section{Abstract}

ICMI is inseparable with the rise of the middle class Muslim communities in Indonesia. This is because the roles and contributions of ICMI are very significant in the development of middle class Muslim communities. Although the establishment of ICMI has its pros and cons, it is undeniable that ICMI's contributions towards development of the Muslim communities are huge. This article aims to identify the roles and contributions of ICMI in the development of middle class Muslim communities in Indonesia in the New Order era. The roles of ICMI are based on education and economic aspects, the consolidation of the Islamic movement in Indonesia aspects, and the political agenda aspects. Based on our findings, we conclude that ICMI is deemed to be the pioneer of middle class Muslim communities' revival in Indonesia especially in the New Order era.

[ICMI tidak dapat dipisabkan dengan kebangkitan masyarakat Muslim kelas menengah di Indonesia. Hal ini disebabkan peran dan kontribusi ICMI sangat signifikan dalam perkembangan masyarakat Muslim kelas menengah. Meskipun pendirian ICMI diliputi pro dan kontra, namun tidak dapat sangkal babwa kontribusi ICMI terhadap pembangunan masyarakat Muslim kelas menengah sangat besar. Artikel ini bertujuan untuk mengidentifikasi peran dan kontribusi ICMI terhadap perkembangan masyarakat Muslim kelas menengah di Indonesia pada zaman Orde Baru. Peran ICMI ini 
ditinjau dari aspek, pendidikan dan ekonomi, aspek, konsolidasi gerakan Islam Indonesia, dan aspek agenda politik. Berdasarkan hasil penemuan, kami menyimpulkan bahwa ICMI dapat dianggap sebagai pelopor kebangkitan masyarakat Muslim kelas menengah di Indonesia terutama pada zaman Orde Baru.]

Keywords: Indonesia, ICMI, middle class Muslim communities, Soeharto, New Order

\section{A. Introduction}

At the time of Soeharto's New Order, the middle class Muslim communities allegedly intended to establish an Islamic state in Indonesia, an ambition strongly opposed by Soeharto. In 1985, he took immediate action to prevent its incurrence. The action taken was to implement Pancasila ${ }^{1}$ as the sole foundation of the country and forced all organisations and political parties to accept it. By doing so, organisations and political parties that practiced the fundamentals of Islam, communists, or certain religions are banned.

Nevertheless, the middle class communities, especially the intellectuals, were deemed as one of the pioneers and drivers of change towards a more democratic society. ${ }^{2}$ The same opinion was also expressed by Pramono, but he termed the Muslim communities as "santri“" (Muslim students). He said that the emergence of new middle class students (new santri) in the 1990s led to the recovery of the country's relationship with the Muslim communities. The middle class new students were formed by the intellectual circle that was active in education and bureaucracy. Pramono provided example of ICMI (Indonesian Association of Muslim

1 The five are belief in God, humanitarianism, national unity, democracy, and social justice. These principles were first enunciated by the nationalist leader Soekarno in a speech on June 1,1945, when Indonesians were preparing to take power from the Japanese at the end of the Pacific War. Soekarno was trying to convince Islamic leaders, who wanted a state based on Islam, to accept his broader formulation, primarily on the grounds that Christian areas would secede from an Islamic Indonesian state, see J.D. Legge, Sukarno: A Political Biography (Sydney: George Allen \& Unwin, 1985).

2 Muhammad A.S. Hikam, Politik Kewarganegaraan: Landasan Redemokratisasi di Indonesia (Jakarta: Erlangga, 1999). 
Intellectuals) as the new rise of the middle class students in Indonesia. ${ }^{3}$ In parallel, the role of ICMI was deemed to be the pioneer of the revival of the middle class Muslim communities in Indonesia. Hefner who examined the background of ICMI's establishment and its roles up to 1993 concluded that the birth of ICMI was an orientation and the struggles of middle class Muslims in political and cultural aspects of modern Indonesia, simultaneously changing the map and the political alliances done by the New Order regime in early 1990s. ${ }^{4}$

There are several articles that discussed ICMI and the emergence of Muslim middle class communities in Indonesia. Muzani (1994), ${ }^{5}$ Muzani (1995), Hefner (1995), Liddle (1996), Rizal \& Liddle (1996), Bertrand (1996), Suryadinata (1997), Hamayotsu (2002) and Salim (2011) debated about the relationship between Soeharto with ABRI (Armed Forces of the Republic of Indonesia) that was not initially harmonious and the establishment of ICMI comprising middle class Muslims which has the blessing of Soeharto. They also discussed the rise of the middle class Indonesian Muslims and Soeharto's change of attitude towards Muslims after the birth of ICMI. Issues of democracy and openness and political interests of Soeharto in ICMI were also discussed.

Unfortunately, their writings are mainly about the relationship between Soeharto and ABRI, the emergence of ICMI, the rise of middle class Muslim communities and Soeharto's political interests in ICMI to maintain his power. Meanwhile, the issue of the role of ICMI against the rise of middle class Muslim communities was forgotten. In fact, the issue of the role of ICMI is very important to be discussed to determine the contributions of ICMI specifically in the development of the middle class Muslim communities and the country's progress in general. Consequently, this article discusses the roles of ICMI in the rise of the middle class Indonesian Muslim communities in the New Order era.

In order to reach this objective, this article has used secondary

3 Pramono U. Tanthowi, Kebangkitan Politik Kaum Santri: Islam dan Demokratisasi di Indonesia 1990-2000 (Jakarta: Pusat Studi Agama dan Peradaban, 2005).

${ }^{4}$ Robert W. Hefner, ICMI dan Perjuangan Menuju Kelas Menengab Indonesia, trans. by Endi Haryono (Yogyakarta: Tiara Wacana, 1995).

5 Saiful Mujani, "Kultur Kelas Menengah dan Kelahiran ICMI", Studia Islamika, vol. 1 , no. 1 (1994), pp. 207-35. 
data by using library research. The required data is collected through library resources such as books, journals authoritative internet materials and any previous works related to the objectives of this article directly or indirectly. These secondary data have been collected for almost six months. Then, these data have been analysed following predetermined themes by using descriptive-analytic method. The using library research based on research approach in order to investigate and explore the role of ICMI to build middle class Muslim communities in Indonesia particularly in the New Order era. Besides, library research was aimed to find out the contributions of ICMI as pioneer of the rising of middle class Muslim communities in New Order era.

\section{B. Middle Class Muslim Communities}

Sociologists generally divide the class of capitalist society into three, namely:

1. The upper class that has the productive resources and hold economic role as investor.

2. The middle class that has educational qualifications or technical training and economic role as white-collar workers or better known as the professionals (management and administration).

3. The lower class that has physical energy and become laborers or manual workers in the production of goods and services. ${ }^{6}$

In modern era, the middle class is the group with most people in the developed and developing countries. However, Suryadinata says that the concept of middle class in the Asian context is unclear. Some refer to Muslim traders, administration officials, and professionals and army personnel. Others restrict it to professionals and entrepreneurs. Referring to the Western definition, the middle class in Indonesia is still small. In 1990, those referred to as the middle class are "professional and technical" and "managers and administrators" groups who comprised only 3.9 percent of Indonesia's population at that time.

According to Karl Marx, farmers, small entrepreneurs and small

${ }^{6}$ Kntayya Mariappan, Ketidaksamaan Sosial (Kuala Lumpur: Utusan Publications, 2000).

7 Leo Suryadinata, "Democratization and Political Succession in Suharto's Indonesia”, Asian Survey, vol. 37, no. 3 (1997), pp. 269-280. 
traders are the remnants of the pre-capitalism economy. This group was known as the middle class which was basically a group from the period of transition. They were also considered as small bourgeoisie that have conservative tendencies mindset. They were ranked between the working class and the capitalist class and landlords. With the existence of the transitional position, it is said to blur the boundaries between the workers and the bourgeois. ${ }^{8}$

Unlike Marx, the founder of modern sociology, Max Weber divided capitalist society economically into five classes, namely (1) the bourgeoisie class, (2) the working class, (3) the educated class, (4) the managers or administrators class, (5) small bourgeoisie, which refers to the traditional small bourgeois made up of businessmen, traders and farmers. This last group was closest to Marx's opinion.9 The middle class itself can be divided into three parts, the upper-middle class, mid-middle class and lower-middle class. ${ }^{10}$

Upper-middle class comprised of professional management and administration of the highest level. Mid-middle class was staffed by other professionals such as doctors, lawyers, engineers, lecturers, accountants, and others. Meanwhile the lower-middle class comprised of low level service workers. ${ }^{11}$ Regardless, what is meant by middle class communities are those whose position are between the working class and the bourgeoisie or between the upper class and the lower class. In the context of this discussion, it is understood that middle class Muslim communities are group of Muslims who are placed between the working class and the bourgeoisie or between upper and lower class communities whose livelihoods are lucrative and well educated.

In Indonesia, the rise of the middle class Muslim communities can be seen from the establishment of ICMI at the end of 1990. ICMI consists of Indonesian Muslim educated leaders or intellectuals and based on the concept of the middle class community described above, they are

8 M. Dawam Rahardjo, Masyarakat Madani: Agama, Kelas Menengah, dan Perubaban Sosial (Jakarta: LP3ES-LSAF, 1999).

${ }^{9}$ Ibid.

10 Noran Fauziah Yaakub, Pengantar Sosiologi (Petaling Jaya: Penerbit Fajar Bakti Sdn Bhd, 1987).

11 Mariappan, Ketidaksamaan Sosial. 
included in the category of middle class community ${ }^{12}$. Therefore, it is not wrong to say that the rise of the middle class Muslim communities in Indonesia relates to the existence of ICMI and the role it plays.

\section{Middle Class Muslim Communities in Indonesia}

The emergence of the middle class Muslim communities in the Dutch colonial era can be seen from the birth of the Syarikat Islam (SI) in the 1910s which had hundreds of thousands of members and Jong Islamieten Bond (JIB), the 1920s Islamic youth organization with its leaders KH. Agus Salim and H.O.S. Tjokroaminoto. Then the establishment of the Masyumi Party in the Old Order period followed. The emergence of middle class Muslims in both eras was more likely to be preceded by political movements and Islamic organisations. This is in contrast to the rise of the middle class Muslim communities in the New Order era which resulted from education and thought movement.

There are three classes of middle class Muslim communities in Indonesia, namely: First, modern elderly, especially Masyumi party supporters, who strived to champion formal political pursuit. ${ }^{13}$ However, since Masyumi was banned and not authorized to carry out political activities, this group changed its struggle by establishing Parmusi (Indonesian Muslim Party). ${ }^{14}$ Secondly, young people who are not directly involved with Masyumi, those who did not form a new party but participated in the New Order political activity through recognised existing parties. They continued to be involved in the bureaucracy and support the modernist movement. ${ }^{15}$ Thirdly, the younger generation. Although this group supported the elderly in the politics and the young people in the bureaucratic matters, their tendency was to build the basic

12 The establishment of ICMI gave rise to hopes on the part of the middle-class Muslims of gaining favors from the government and access to the formal channels of influence, see Kikue Hamayotsu, "Islam and Nation Building in Southeast Asia: Malaysia and Indonesia in Comparative Perspective", Pacific Affairs, vol. 75, no. 3 (2002), pp. 353-375.

13 M. Dawam Rahardjo, Intelektual Intelegensia dan Perilaku Politik Bangsa: Risalah Cendekiawan Muslim (Bandung: Penerbit Mizan, 1993).

14 Bahtiar Effendy, Islam dan Negara; Transformasi Pemikiran dan Praktik Politik Islam di Indonesia (Jakarta: Paramadina, 1998).

15 Rahardjo, Intelektual Intelegensia dan Perilaku Politik Bangsa. 
structure necessary to support a more democratic political system. In other words, this group was more interested in community development activities and engaged in the fields of thought and education, rather than political or bureaucratic matters. ${ }^{16}$

There are five phenomenons behind the rise of the Indonesian middle class Muslim communities in the 1980s and early 1990s, as follows:

\section{Wearing Headscarf as Muslim Identity}

The Islamic Revolution of Iran which erupted in 1979 has influenced the world's Muslims psychologically. After being marginalised for a long time, the Islamic revolution in Iran gave a new identity and pride to Muslims, including in Indonesia. Since the early 1980s, Indonesian Muslim women began to wear the headscarf proudly. Following the victory of the Islamic Revolution of Iran, the phenomenon of wearing the headscarf in Indonesia has become a symbol of Islamic resistance to Western cultural hegemony. Since the 1980s, the influence of this revolution has been strong in the Indonesian Muslim communities. According to Fathonah K. Daud, who studied about headscarf and aurat of women, the phenomenon of wearing headscarf in Indonesia was caused by two factors. Firstly, the external factor, which is the influence of Ikhwan al Muslimin's thinking and the Islamic Revolution in Iran that occurred in 1979. According to him, the influence of the Muslim Brotherhood and the Iranian Revolution was fast affecting some of Indonesia's communities at that time.

Secondly is the internal factor in which Soeharto's policies on Muslims have been considered to marginalise the Muslims. But in the early 1990s, when Soeharto's relationship with the Muslim communities improved, the New Order government automatically began accepting wearing headscarf amongst Muslim women and was no longer considered as a symbol against the New Order regime. ${ }^{17}$ So it is not surprising that in the late 1980s, women wearing headscarf were considered conservative and stupid. Students, undergraduates, and lecturers who wore the

${ }^{16}$ Ibid.

17 Fathonah K. Daud, "Jilbab, Hijab dan Aurat Perempuan: Antara Tafsir Klasik, Tafsir Kontemporer dan Pandangan Muslim Feminis", Al Hikmab: Jurnal Studi Keislaman, vol. 3, no. 1 (2013), pp. 1-24. 
headscarf were considered a fanatic and radical that must be eliminated. While in the work place, headscarf was considered as unprofessional and not performing, so sometimes women wearing headscarf were not accepted to work at certain places. If accepted, her career will be blocked by her boss. ${ }^{18}$

Yet in the 1990s, many women, especially among Muslim undergraduates emerged covered, while carrying the Qur'an in their hands. Many of them were seen in public places such as on the streets, universities, shopping malls, or in buses. They proudly wore Muslimah clothing everywhere, making it popular amongst students in the city. Islamic identity in the form of Muslimah clothing has become a pride in the big city. It was then widely disseminated amongst Muslim women and female students which eventually touched the middle class. Within the middle class, the Muslimah dress gave another meaning. It is not just the expression of religious consciousness but socially it functions as the reinforcement of the identity and symbol of the resurrection of the middle class. Suzanne Brenner's study on the use of headscarf among Javanese women showed that the widespread use of headscarf in the 1980s among Muslim women has reinforced the spirit and identity of Muslim women in Java. ${ }^{19}$

\section{E. Modern Islamic Music (Qasidah)}

When wearing a headscarf was popular in the 1980s, at the same time, when the veil was popular, on the other hand in the 1980s, there was also a musical expression that sang a modern qasidah that became the symbol of religion (Islam) and spiritual among the educated society in urban areas. Qasidah was deemed to be the answer to the spiritual emptiness of the Muslim communities at that time. It has a modern characteristic compared to previous qasidahs and pop-like genre. The modern qasidab famous at that time was from the Bimbo group. Through this middle class special modern qasidah, the Bimbo group introduced

18 Besse Risnayanti and Hafied Cangara, "Jilbab Sebagai Simbol Komunikasi di Kalangan Mahasiswa Universitas Hasanuddin: Studi Komunikasi Nonverbal", KAREBA : Jurnal Ilmu Komunikasi, vol. 1, no. 2 (2016), pp. 149-76.

19 Suzanne Brenner, "Reconstructing Self and Society: Javanese Muslim Women and 'The Veil”', American Ethnologist, vol. 23, no. 4 (1996), pp. 673-97. 
another Islamic symbol that reinforced the identity of the Islamic religion among the middle classes. The modern qasidah songs were aimed at bringing the taste of religious music to the Muslim communities living in urban areas. ${ }^{20}$

The acceptance of the middle class Muslim communities towards Bimbo's modern qasidah music in the 1980s was because they were seeking "the expression of peaceful, calming and soothing religious beauty". ${ }^{21}$ It is an alternative to traditional qasidah dominated by Arabic instruments, songs and poems. Bimbo presented the different colors of qasidah music that were dominated by modern musical instruments such as guitar, drum and others. The songs that Bimbo sung were popular among the Muslim middle class. As a well-known Islamic music band, Bimbo is often invited to sing their qasidah songs on television. Their appearance on television caused a lot of people to watch and indirectly spread Islam at that time.

\section{F. Publications with Islamic Nuances}

The development of Islam in Indonesia in the 1980s and 1990s was also highlighted by the emergence of Islamic nuanced publishers or printed media. One of the most popular is Ulumul Qur'an Journal. The Ulumul Qur'an Journal was first launched in 1989. The editor was Dawam Rahardjo, an intellectual, NGO activist and one of the founders of ICMI. This Islamic publication was professionally managed and raised the issues of pluralism, liberalism and inclusiveness. Its writing style also showed that there has emerged an educated element of society, that is the middle class Muslim communities. Compared with other Islamic media, Ulumul Qur'an Journal was the most appreciated liberal Islamic Journal in Indonesia. ${ }^{22}$

Before the 1980s, the Islamic publishing media was synonymous with the discussion of figh, morality, taubid with traditional and unattractive lay outs and formats. The presence of Ulumul Quran Journal affirmed

20 Tatang Sumarsono, Sajadah Panjang Bimbo: 30 Tabun Perjalanan Kelompok Musik Religius (Jakarta: Mizan, 1998).

21 Mariana Ramelan, “Tahajudku Cuma Untuk Keluarga”, Ummat, vol. 1, no. 16 (1996), pp. 87-9.

22 Robert W. Hefner, "Print Islam: Mass Media and Ideological Rivalries among Indonesian Muslims”, Indonesia, no. 64 (1997), pp. 77-103. 
the emergence of the middle class Muslim communities. Through this medium the Muslim middle class found their expression in the aspects of publishing, thinking and Islamic materials. Thereafter, several other publishers emerged up with similar features, particularly for Muslim middle classes, such as Mizan, Paramadina Publishers, LKiS, Pustaka Pelajar, Pustaka, Qalam and others.

The presence of the Ulumul Quran Journal was seen to be very different compared to the publications before the 1980s. The obvious difference is that in the case where the issue raised could not be separated from the question of pluralism and liberalism. The liberalness of this journal can be seen from its features as follows: First, Ulumul Quran Journal threatened already established understanding in Islamic Indonesia. This is evident from the journal's support of the movement of Islamic reforms voiced by Nurcholish Madjid. Secondly, Ulumul Quran Journal always conducted dialogues, seminars, and religious discussions with people from different religions. This was done by raising the theme of religious pluralism and publishing writings from non-Muslim. ${ }^{23}$ Thirdly, this journals highlighted broader themes such as science and technology, Islamic knowledge, future of Islam, orientalism, religious literature, traditional Islamic mosaics, tasawnf and Islamic mysticism, Islam and postmodernism, Islamic reform, Islamic development in the West, Islamic philosophy, human rights, and gender. The richness of the theme highlighted in the Ulumul Quran Journal, has placed and raised the reputation of Ulumul Quran Journal as the most courageous journal in the Islamic world. ${ }^{24}$ The richness of the theme and courage of this journal has never been found in conventional Islamic media that existed before the 1980s.

23 The Ulumul Quran Journal has published articles of non-Muslims, including the writings of R. William Liddle, an American Indonesianist. Please read his writings in. "Scripturalism Media Dakwah: Satu Bentuk Pemikiran dan Aksi Politik Islam Masa Orde Baru”, Ulumul Qur'an, vol. 4, no. 3 (1993), pp. 53-65. Nevertheless, Dawam Rahardjo, as editor-in-chief, explained that the Ulumul Quran Journal is an academic journal. This is because the journal is available to anyone including non-Muslim authors. Articles from non-Muslim authors are needed as comparative materials, see Rahardjo, Intelektual intelegensia dan perilaku politik bangsa.

24 Hefner, "Print Islam". 


\section{G. Held a Recitation in the Hotels}

Since the 1980s, the typical middle-class recitation phenomenon has emerged and proliferated in star-rated hotels, luxury offices, televisions and other prestigious venues. Paramadina pioneered the recitation of packages in the form of religious courses with high fees at the hotel. Some successful businessmen such as Abdul Latief, owner of Pasaraya Mall and Director of Sarinah Jaya, and Ahmad Ganis, Director of PT. Radiant Utama, in collaboration with Nurcholish Madjid, Dawam Rahardjo and Fahmi Idris founded the religious studies club Paramadina in 1986.

In January 1999, 50 executives from various companies participated in a program called "Pesantren Eksekutif" (Executive Boarding School) held at Giri Gahana Golf \& Resort in Jatinangor, Bandung. For three days they tried to clear their hearts on the show for the future of a better life. The event was organized by PT. Bimantara Citra, a company owned by Bambang Triatmodjo, the son of former President Soeharto. This program is held every month for three years of Ramadhan. Each participant paid Rp. 350,000 for three days. In 1999, more than 110 executives enrolled but only 50 were accepted due to accommodation capacity issues. The same program was also held in several hotels in Jakarta such as Hilton Hotel, Senayan, for three days 8-10 January 1999. Here, every executive must pay registration to Rp. 950,000 for three days. ${ }^{25}$ Due to the participants are executives, the cost becomes very expensive. Types of recitation like that are still many more in big cities in Indonesia since the 1980s in line with an increasingly extensive Islamization process.

\section{H. The Existence of ICMI and the Resurgence of Middle Class Muslim}

From the above four phenomenons, ICMI's birth is characterized as the most powerful phenomenon in the rise of the middle class Muslim communities in Indonesia. After the existence of ICMI in the late 1990s, middle class Muslim communities began to have the power to engage in the circle of power. ICMI, a modern Islamic organisation representing the Muslim middle class, grew and developed into a significant middle class power. According to Arief Budiman, this Muslim middle class has had

25 Herry Mohammad and Taufik Abriansyah, "Pesantren Eksekutif: Agar Tak Menohok Kawan", Gatra (1999), p. 70. 
a big and rapid influence in the dynamism of Islam in Indonesia. ICMI at the time was not only very influential but also expanding rapidly and vastly. ${ }^{26}$ Liddle mentioned in ICMI's second congress in Jakarta, "Twelve hundred delegates, representing 42,000 members from all Indonesian provinces and from many Indonesian Islamic communities abroad, participated. Minister of Research and Technology, B. J. Habibie, generally considered President Soeharto's favorite cabinet member, was chosen for a second five-year term as national chair. Sixteen ministers, nearly half the cabinet, were elected to the top positions, and the president himself was designated as ICMI's "Protector" (Pelindung)". ${ }^{27}$

For the middle class communities in the urban areas, ICMI has become a symbol of the rise of the Muslim communities. In addition, ICMI has also become a symbol of modern Islamic identity in which Muslims no longer feel marginalised. Previously, Muslims were synonymous with poverty, backwardness, and the Muslims tend to feel inferior with their religion, but now Islam is no longer seen as the religion of the losers. ${ }^{28}$ In other words, through ICMI, Islam showed its modern image. Its impact in the 1990s, in which ICMI's modernity has provided a reference for many Muslims to boldly demonstrate their Islamic identity. This phenomenon ultimately spread to staff and government officials where they no longer feel embarrassed to show their Islamic identity. This Islamic expression continued to spread to government and private offices, hotels and so on.

The rise of the Muslim middle class has made the position of Muslims drastically changed politically and has a high bargaining position. The Muslim middle class who was previously marginalised, became an influential movement in the center of power and was creating a new balance in pluralist Indonesian society. Many of the middle class Muslims sat in the cabinet and the parliament. Due to the large influence of Islamic

26 Arief Budiman, "From Lower to Middle Class: Political Activities Before and After 1988", in Democracy in Indonesia: 1950s and 1990s, ed. by J.D. Legge and David Bourchier (Clayton, Victoria: Centre of Southeast Asian Studies, Monash University, 1994).

27 R. William Liddle, "The Islamic Turn in Indonesia: A Political Explanation”, The Journal of Asian Studies, vol. 55, no. 3 (1996), pp. 613-34.

28 Michael R.J. Vatikiotis, Political Change in Southeast Asia: Trimming the Banyan Tree (London and New York: Routledge, 1996). 
politics at the time and quite a lot of students sitting in government, William Liddle called the 1990s as "Islamic Turn in Indonesia"29.

\section{Establishment of ICMI}

In line with development of time, current middle class Muslim communities are expanding and varied, including in Indonesia. Just to mention, middle class Indonesian Muslim communities are made up of scholars, preachers, civil servants, workers in the private sector and more. When Soeharto was elected as President, the fate of Muslims was increasingly sidelined. They were not given opportunity to play a role in developing and advancing the country. In the era of the 1970s and 1980s, the Muslims were not given ample opportunity by the government to also play a role in politics. They allegedly wanted to replace the Pancasila state foundation to Islam (anti-Pancasila).

In addition to repressive measures, the New Order also limited the social, political, and religious activities of Muslims. Among them was the rejection of the restoration of Masyumi's image, an Islamic based political party that was banned at the time of Soekarno in 1960, the policy to unite Islamic parties into a single party, which was the United Development Party (PPP) starting 5 June $1972 .{ }^{30}$ As for the socio-religious context, the Soeharto regime implemented the "mandatory report" to anyone who would be conducting activities. The rule was that "all meetings involving more than five persons must obtain permission from the police. ${ }^{31}$ This matter narrowed the space for Muslims to participate in developing and advancing the country.

When Soeharto's relationship with ABRI became disharmonious, he tried to turn his attention to the Muslims. This was because Muslims were seen to have the potential in developing the country, as well as to balance the power of ABRI which was giving less support to the leadership of Soeharto. ${ }^{32}$ L.B. Moerdani, Minister of Defense and Peace

29 Liddle, "The Islamic Turn in Indonesia".

30 Afif Sholahuddin, Membangun Centrum Gerakan di Era Liberalisasi. Jakarta: PB PMII, 2004).

31 Hefner, ICMI dan Perjuangan Menuju Kelas Menengah Indonesia.

32 Dadang Juliantara, "Kelas Menengah Muslim dalam Medan Perubahan: Sebuah Catatan tentang ICMI”, in ICMI Negara dan Demokrasi: Catatan Kritis Kaum Muda, 
1988-1993, deemed the more influential and have a strong influence in ABRI caused Soeharto to be cautious for fear that ABRI would weaken his position as president. Therefore, Soeharto changed and appointed "his men" who were faithful to several positions in ABRI. ${ }^{33}$

In addition, in the mid-1980s, Indonesian Muslims began to accept Pancasila as the sole foundation of the country. In this case, Soeharto thought that there will be no threat from Muslims to oppose Pancasila as the state ideology and establish an Islamic state. Although Muslims were sidelined from the country's development and political aspects, in terms of cultural aspects and social life, Muslims were said to have risen very progressively and had a bright future. ${ }^{34}$ Matters such as these made Soeharto more comfortable to choose the Islamic groups as allies to maintain the status quo as Indonesian president in the next election. In fact, Hefner stated that after the pilgrimage, Soeharto added Muhammad as his first name. ${ }^{35}$ This suggested that Soeharto effort to bridge the relationship with Muslims was as a political interest.

The rise of Islam and the middle class Muslim communities in Indonesia began with the establishment of ICMI at the end of 1990 in conjunction with the National Symposium of Muslim Scholars at the Student Center, University of Brawijaya, Malang on 6-8 December 1990. On 6 December 1990 in Malang, with traditional pondok (Islamic school) students attire ${ }^{36}$, while uttering Bismillabirrahmanirrabim, President Soeharto inaugurated the National Symposium entitled "Muslim Intellectuals: Developing Society of XXI Century". ${ }^{37}$ Then, 7th December was set as the birth date of ICMI. The three-day symposium was attended by some 500 Muslim scholars throughout Indonesia. ${ }^{38}$

ed. by Zuli Qodir and Lalu M. Iqbal Songell (Yogyakarta: Kelompok Studi Lingkaran Pustaka Pelajar, 1995).

33 Douglas E. Ramage, Percaturan Politik di Indonesia: Demokrasi, Islam, dan Ideologi Toleransi, trans. by Hartono Hadikusumo (Yogyakarta: Matabangsa, 2002).

34 Tanthowi, Kebangkitan Politik Kaum Santri.

35 Hefner, ICMI dan Perjuangan Menuju Kelas Menengah Indonesia, p. 89.

36 Ibid.

37 M. Syafi'i Anwar (ed.), ICMI: Kelabiran dan Misi (Jakarta: Departemen Pembinaan Sumber Daya Manusia ICMI, 1994).

38 A. Makmur Makka and Dhurorudin Mashad, ICMI: Dinamika Politik Islam di Indonesia (Jakarta: Pustaka CIDESINDO, 1997). 
The establishment of ICMI is in fact an initiative of students from the Faculty of Engineering, Universitas Brawijaya who merged the Islamic spirituality groups at the university. The background of the establishment of ICMI stemmed from the polarisation in the leadership of the Muslims. ${ }^{39}$ There are a number of Islamic groups in Indonesia, such as Paramadina in Jakarta, Salman in Bandung and Al-Fatah in Surabaya with each standing alone without forming a larger Islamic organisation, so much so that their ideas and thoughts were not integrated and mutually reinforcing.

\section{J. Pros and Cons of ICMI Birth}

The establishment of Islamic-based scholar organisations turned out to be warmly received from middle class Muslim communities especially among the intellectuals. Apart from Indonesian Muslims and education figures, the symposium was also attended by cabinet ministers. Leaders from the Muslim and education circles present included Prof. Dr. Harun Nasution, Prof. Dr. A. Baiquni, Dr. Amin Rais, Dr. Nurcholis Madjid, Dr. Muslimin Nasution, and Dr. Sri Bintang Pamungkas. While among the cabinet ministers were B.J Habibie (Minister of Research and Technology), Emil Salim (Minister of Environment), Munawir Sjadzali (Minister of Religion), Azwar Anas (Minister of Transportation) and Fuad Hassan (Minister of Education and Culture). The symposium was officiated by Indonesian President Soeharto at that time, whom finally chose and appointed B.J. Habibie as the first head of ICMI. ${ }^{40}$ At the second General Assembly of ICMI in 1995, B.J. Habibie was reelected as head of ICMI and President Soeharto was appointed as patron. ${ }^{41}$

B.J. Habibie's appointment, who is also a minister in Soeharto's cabinet as the first Head of ICMI in 1990 and Soeharto's willingness to be the patron of this organisation, made ICMI as the only Islamic organisation (based on Pancasila) fully supported by the government. Support received from the government has opened a larger space for ICMI to communicate ideas, vision and criticism over the government's

\footnotetext{
39 "Ibid.; Liddle, "The Islamic Turn in Indonesia".

40 Makka and Mashad, ICMI.

41 Liddle, "The Islamic Turn in Indonesia”; Robert W. Hefner, "Global Violence
} and Indonesian Muslim Politics", American Anthropologist, vol. 104, no. 3 (2002), pp. 754-65. 
policies that affect the interests of the Muslim communities. However, ICMI friendly relations with the government received criticism from various quarters. They regarded that the ideas, visions and criticisms from ICMI to the government ineffective because the main leaders of ICMI are people who are in the government itself.

The presence of the cabinet ministers and President Soeharto who officiated the symposium has attracted a variety of negative public reaction. They criticized that the formation of ICMI was simply as a "license" for the government to make ICMI a tool for the benefit of their administration. ${ }^{42}$ The critics say that ICMI only served as a tool of the government so that there is no place for them to criticize and give independent and open recommendations to the government. ICMI was seen as a counterweight $\mathrm{t}^{43}$ or counterbalance measures ${ }^{44}$ over the powers of ABRI by Soeharto. This is due to the increasing dominance of ABRI and Soeharto was worried by this situation, not to mention the relationship between Soeharto and leaders of ABRI at that time began to deteriorate. ${ }^{45}$

In addition, ICMI was also considered a primordial organisation. Abdurrahman Wahid (Gus Dur), whom at that time served as Head of PB-NU (Committee Members-Nahdlatul Ulama/The Awakening of Traditional Religious Teachers and Scholar), refused to join ICMI as he considered its primordial nature will divide the nation's and scholars' integration and would not help in catalysing national development. ${ }^{46} \mathrm{He}$ also mentioned that ICMI had exclusive stance, sectarian, anti-Pancasila, manipulated Islam and merely a Muslim organisation "exploited" by Soeharto for political purposes only. ${ }^{47}$

Another NU figure, Chalid Mawardi, questioned the importance

42 Ramage, Percaturan politik di Indonesia.

43 David McKendrick, "Indonesia in 1991: Growth, Privilege, and Rules", Asian Survey, vol. 32, no. 2 (1992), pp. 103-110.

44 Jacques Bertrand, "False Starts, Succession Crises, and Regime Transition: Flirting with Openness in Indonesia", Pacific Affairs, vol. 69, no. 3 (1996), pp. 319-340.

45 Andrew MacIntyre, "Indonesia in 1993: Increasing Political Movement?", Asian Survey, vol. 34, no. 2 (1994), pp. 111-118.

46 Makka and Mashad, ICMI.

${ }^{47}$ Ramage, Percaturan Politik di Indonesia; Liddle, "The Islamic Turn in Indonesia”; Makka and Mashad, ICMI; Ahmad Bahar, ICMI: Kekuasaan dan Demokrasi (Yogyakarta: APena Cendekia Indonesia, 1995). 
of the establishment of ICMI, especially when associated with politics. Chalid argued that the establishment of ICMI was merely a political manipulation. He added since the existence of ICMI was merely as a political manipulator, then this organization would only be exclusive and not giving attention to the social problems happening at the grassroots level. ICMI was deemed to give more attention to the development of science and technology and modern management with sophisticated system, to the extent that the problems of poverty, injustice and democracy in the lower strata of society were not given the attention it deserves. $^{48}$

Iqbal Assegaf, Head of the Indonesian Islamic Students Movement (PMII) from 1988 to 1991, expressed the same opinion about the establishment of ICMI. He said the existence of ICMI will not give any benefit to the middle class Muslim. Since the existence of ICMI was as a political manipulator, which would only channel political aspiration of ICMI members, then ICMI should not be established. ${ }^{49}$

However, the allegation that ICMI was an organisation that is primordial and would not affect the development of the country, and disrupted national integration was purely seen from a political standpoint. In fact, the existence of ICMI should be viewed from the perspective of the importance of culture, social, goals, mission and impact that would arise from ICMI in the national development and middle class Muslim interests. According to Emha Ainun Najib, an Indonesian cultural figure, ICMI is like a vehicle. He gave an example, to go to Jakarta, one can use a wide range of transportation such as bus, train, airplane, car, motorcycle and even "crawl". Whatever vehicle is used, it is not important. What matter is the destination is Jakarta. ${ }^{50}$

Amin Rais, General Head of Muhammadiyah (1995-2000), said that the existence of ICMI in the midst of the Indonesian society was indispensable because at that time there wasn't any organisation that brings together Muslim scholars with different work background. He added that the existence of ICMI was needed to overcome the backwardness of Muslims in Indonesia in the field of science and technology and the

\footnotetext{
${ }^{48}$ Makka and Mashad, ICMI.

${ }^{49}$ Ibid.

${ }^{50}$ Ibid.
} 
social problems rampant in Muslim communities due to the impact of science and technology ${ }^{51}$

In connection with the assumption that Soeharto "takes advantage" of ICMI for his political interests, Hasan Basri, Head of MUI (Indonesian Ulama Council) 1984 to 1990, said that ICMI is not a vassal of the ruling party. ICMI is only cooperating with the government to develop the nation and country. ${ }^{52} \mathrm{M}$. Dawam Rahardjo reiterated Hassan Basri's statement that the relationship between ICMI and the government is a partnership in order to build and develop the country..$^{53}$ Therefore, ICMI can deliver its voice without fear of being blocked by the government to form Muslim communities (not Islamic country) in Indonesia. The Muslim communities meant that the nature of national legislation is imbedded with the values of Islam. ${ }^{54}$

\section{K. ICMI's Roles in the Rise of Middle Class Muslim Communities in Indonesia}

ICMI's roles in advancing middle class Muslim communities can be seen from education and economic sectors, the consolidation of the Islamic movement in Indonesia sectors, and the political agenda sectors. In the education sector, ICMI has provided scholarships to middle class Muslim students who studied at any university in Indonesia through the established Abdi Bangsa Foundation..$^{55}$ Although the government has provided scholarships to outstanding students, it is not focused on Muslim students only but also non-Muslims. Unlike the government, the ICMI only granted scholarships to middle class Muslim students. In addition, the establishment of Insan Cendekia School which is a high performing school can be deemed to be a contribution by ICMI in the field of education pioneered by B.J. Habibie. ${ }^{56}$

51 Ibid.

52 Ibid.

53 Ahmad Baso, Civil Society versus Masyarakat Madani: Arkeologi Pemikiran "Civil Society” dalam Islam Indonesia (Bandung: Pustaka Hidayah, 1999).

54 Ramage, Percaturan Politik di Indonesia.

55 Ibid.

56 The school was founded in 1996, a brainchild of B.J. Habibie where his education system incorporates the concept IPTEK (Science and Technology) and 
Meanwhile in the economic field, ICMI managed to realise its goal to help the progress of the middle class Muslim communities through the establishment of Bank Muamalat, Bank Perkreditan Rakyat (BPR) and Bank Syariah. ${ }^{57}$ The establishment of these Islamic banks (other than BPR) is seen as a counterweight to the conventional banks which were growing rapidly, generally controlled and owned by non-Muslims. Therefore, as the followers of the largest religion in Indonesia, the Muslim communities should have its own bank with Islamic-based operational systems. ICMI also established PINBUK (Small Business Incubation Center) in 1995 to encourage middle class Muslims to become entrepreneurs, especially small and medium sized business sector. ${ }^{58}$ While ALISA Khadijah (Indonesian Muslim Association of Entrepreneurs) which was established in 1997, is an entrepreneur organisation under the auspice of ICMI that is specifically intended for Muslim women. ${ }^{59}$

The second objective of ICMI is to unite the various movements or sects of Islam in Indonesia. Separation of the two largest Muslim organisations in Indonesia that were NU which was perceived as traditional and Muhammadiyah as modern was irrelevant. Nasir Tamara, one of the main leaders of ICMI, said that the purpose of ICMI is as a place where "all Muslims (from different movements and sects) can meet". ${ }^{60}$ Abdurrahman Wahid criticism against the establishment of ICMI widen the gap between NU and ICMI - government, so much so that many leaders of NU and its members express their dissatisfaction over the attitude of the Head of PB-NU. Anyway, in the end Abdurrahman Wahid gave freedom to NU members to join ICMI. ${ }^{61}$ Some NU members who joined ICMI were Yusuf Hasyim (NU figure who is the uncle of Abdurrahman Wahid), Ali Yafie (former Rais Am of NU) and Achmad

IMTAK (Faith and Piety). This school is a full boarding school located in Serpong, Banten and Gorontalo, Sulawesi, please see http://manicserpong.com/sejarah-insancendekia-dan-bj-habibe/, accessed 5 June 2017.

57 Makka and Mashad, ICMI.

${ }^{58}$ For further information, please refer to http://pinbuk.id/ accessed 5 June 2017.

59 For further information, please refer to http://www.icmi.or.id/lembaga/ view/alisa_khadijah, accessed 5 June 2017.

60 Ramage, Percaturan Politik di Indonesia.

61 Tanthowi, Kebangkitan Politik Kaum Santri. 
Buchori Masruri (NU Regional Head of Central Java). While Amin Rais (General Head of Muhammadiyah) and Din Syamsuddin (Youth Head of Muhammadiyah) was a representative of the ICMI. ${ }^{62}$

ICMI's political agendas as the third goal are demilitarisation ${ }^{63}$, democratisation and proportionalisation ${ }^{64}$. In the process of demilitarisation as stated by ICMI, although this objective has not been successful, it has affected the relationship between ICMI and ABRI. Dawam Rahardjo, an ICMI figure, said disagreements over the nomination of General Try Sutrisno (Commander of ABRI 1988 to 1993) as a candidate for 6th Vice President of the Republic of Indonesia. Instead, Dawam mentioned that B.J. Habibie was the most qualified for the position to accompany President Soeharto. Dawam's statement was regarded by senior ABRI leaders that ICMI is an anti-ABRI organisation. The ICMI - ABRI relationship deteriorated when ABRI described ICMI as an extremist organisation and seeks to establish an Islamic state in Indonesia. ${ }^{65}$

ABRI realised that when demilitarisation which is one of ICMI's political agenda is agreed by the government, the role of ABRI in politics would be significantly reduced or even abolished. Therefore, ABRI would do anything to prevent ICMI's political agenda from happening. Although the goal of demilitarisation has not been successful, at least ICMI has managed to raise discourse on the elimination of ABRI's involvement in the Indonesian political arena. Therefore, it could open the minds of the people that the involvement of ABRI in politics is not necessary because it could narrow the democratic space.

As for the agenda of democratisation, leaders of ICMI such as

${ }^{62}$ Ramage, Percaturan Politik di Indonesia.

63 Demilitarisation means to abolish the space for ABRI to play a political role. As already known, prior to the enactment of the reform, ABRI played an important role in Indonesian politics through the ruling party at that time, Golkar. Many from ABRI and former ABRI became managers and committee members of Golkar.

${ }^{64}$ In this context, what is meant by proportionalisation is ICMI demanded that key positions in ABRI, parliament and the cabinet must be rationalised with the number of followers of existing religions in Indonesia. Since the number of Muslims in Indonesia was 88 percent, it is fitting that 88 per cent of the important positions in ABRI, parliament and the cabinet were given to Muslims.

65 Ramage, Percaturan Politik di Indonesia. 
Adi Sasono, Din Syamsuddin, Imaduddin Abdurrahim, Sri Bintang Pamungkas and Dawam Rahardjo agreed that a more transparent and independent political system was needed in Indonesia. However, there was a difference of opinion among them about whether democracy is the main goal or not. Imaduddin Abdurrahim was one of the leaders who agreed with democracy, but: when people are still ignorant, backward and poor, I do not require the existence of democracy. ${ }^{66}$

Although the realisation of democratisation in Indonesia was not going well at the time, the space for freedom of expression began to open up. In this case, ICMI managed to publish its own newspaper, Republika, in 1993 as a medium for them to convey thoughts, ideas, thoughts or criticism. The interesting fact is that the capital of the newspaper was funded entirely by Muslims. ${ }^{67}$ The emergence of Republika was considered a competitor to Kompas, a newspaper dominated by Christians. ICMI also managed to establish CIDES (Center for Information and Development Studies), a body which examines the development of the Indonesian middle class Muslims. Some Indonesian scholars considered that CIDES is a competitor to the CSIS (Center for Strategic and International Studies) owned by Christian. ${ }^{68}$

ICMI's last political agenda is proportionalisation. In this context, ICMI required that key positions in ABRI, parliament and the cabinet must be rationalised with the number of followers of existing religions in Indonesia. This was because during Soeharto's ruling, key positions were always occupied by Christians. As the number of Muslims was higher than followers of other religions, by almost 88 percent, then the provision for the Muslims for these important positions had to be larger. This political agenda was somewhat successful when Soeharto announced a new cabinet lineup shortly after Golkar's and Soeharto's victory in the 1993 general election. In his cabinet lineup, Soeharto reduced the number of ministers and in parliament who were Christians.69 Similarly

66 Ibid.

67 Makka and Mashad, ICMI.

${ }^{68}$ Ramage, Percaturan politik di Indonesia; Saiful Mujani, "Mitos Politik Aliran dan Aspirasi Politik ICMI Modernis”, Studia Islamika, vol. 2, no. 1 (1995), pp. 209-42.

69 Suryadinata, "Democratization and Political Succession in Suharto's Indonesia". 
for key positions in ABRI. Soeharto appointed General Feisal Tanjung as Commander of ABRI. Subsequently in 1995, he appointed General Hartono who has close ties to Muslim clerics as the Army Chief of Staff. ${ }^{70}$ Feisal Tanjung and Hartono are both known as Muslim who have close ties with B. J. Habibie and ICMI. ${ }^{11}$

\section{A Glimpse of Development of the ICMI during the Reform Era}

The significant role of ICMI in the development of middle class Muslims during the New Order era has made it a great and very important Islamic organization. Moreover when Habibie was in power after the fall of the New Order in 1998. However, since the fall of the New Order, the ICMI's role has not been significant, even as it has been drowned during the reform era. All circles, including ICMI's own cadres, acknowledged that after Habibie failed to maintain his power, ICMI's subsequent efforts faded. ${ }^{72}$ Moreover, the figure of post-reform ruler is Abdurrahman Wahid. The figure who from the beginning criticized the existence of ICMI, and also refused to join ICMI. This situation persists when Indonesia is under Megawati, Susilo Bambang Yudhoyono and President Jokowi. We are not sure, why this scenario could happen, maybe further studies have to be carried out.

\section{Concluding Remarks}

Muslims in the New Order were sidelined by the government due to the reason that they wanted to establish an Islamic state in Indonesia. This led to Muslims not able to play a more active role in developing the country and Muslims themselves. However, in the late 1980s, at the time when Soeharto's relationship with ABRI deteriorated, Soeharto's attitude toward the Muslims changed. At the same time, most middle class Muslim communities sought to create one Muslim organisation in which all Muslim leaders from various organisations can unite. For this reason, the ICMI was born in 1990 in which Soeharto himself became its patron.

70 Rizal Mallarangeng and R. William Liddle, "Indonesia in 1995: The Struggle for Power and Policy”, Asian Survey, vol. 36, no. 2 (1996), pp. 109-116.

71 Ramage, Percaturan Politik di Indonesia.

72 Guntoro Saparie, “Upaya Revitalisasi ICMI Jateng”, Suara Merdeka (2006). 
The existence of ICMI has raised controversy among the middle class Muslim communities themselves. This was due to the support given by the government to ICMI previously unprecedented in the history of Islamic organisations in Indonesia during the New Order. Thus, according to opposing parties, ICMI was just the government's servant so it would not be free to submit ideas, suggestions or criticism on government policies particularly related to matters of middle class Muslims. Furthermore, the Head of ICMI, B. J. Habibie was within the government. Meanwhile, its supporters would defend ICMI with various arguments. Among the argument they put forward was that ICMI is not a government servant but as a partner in building and developing the country and the middle class Muslims of Indonesia.

Notwithstanding, in spite of the controversies, ICMI managed to position itself as a pioneer in the revival of the middle class Muslim communities in Indonesia. This can be seen from the roles it played in terms of education and the economy, unifying the Islamic movements in Indonesia, their involvement in the political sector such as demilitarisation, democratisation and proportionalisation that have major impact on the middle class Muslim communities in Indonesia. 


\section{BIBILIOGRAPHY}

Anwar, M. Syafi'i (ed.), ICMI: Kelabiran dan Misi, Jakarta: Departemen Pembinaan Sumber Daya Manusia ICMI, 1994.

Bahar, Ahmad, ICMI: Kekuasaan dan Demokrasi, Yogyakarta: APena Cendekia Indonesia, 1995.

Baso, Ahmad, Civil Society versus Masyarakat Madani: Arkeologi Pemikiran "Civil Society” dalam Islam Indonesia, Bandung: Pustaka Hidayah, 1999.

Brenner, Suzanne, "Reconstructing Self and Society: Javanese Muslim Women and 'The Veil", American Ethnologist, vol. 23, no. 4, 1996, pp. 673-97.

Budiman, Arief, "From Lower to Middle Class: Political Activities Before and After 1988", in Democracy in Indonesia: 1950s and 1990s, ed. by J.D. Legge and David Bourchier, Clayton, Victoria: Centre of Southeast Asian Studies, Monash University, 1994.

Daud, Fathonah K., "Jilbab, Hijab dan Aurat Perempuan: Antara Tafsir Klasik, Tafsir Kontemporer dan Pandangan Muslim Feminis”, Al Hikmab: Jurnal Studi Keislaman, vol. 3, no. 1, 2013, pp. 1-24.

Effendy, Bahtiar, Islam dan Negara; Transformasi Pemikiran dan Praktik Politik Islam di Indonesia, Jakarta: Paramadina, 1998.

Guntoro Saparie, “Upaya Revitalisasi ICMI Jateng”, Suara Merdeka, 2006.

Hamayotsu, Kikue, "Islam and Nation Building in Southeast Asia: Malaysia and Indonesia in Comparative Perspective", Pacific Affairs, vol. 75, no. 3, 2002, pp. 353-375 [http://dx.doi.org/10.2307/4127290].

Hefner, Robert W., ICMI dan Perjuangan Menuju Kelas Menengah Indonesia, trans. by Endi Haryono, Yogyakarta: Tiara Wacana, 1995.

----, "Print Islam: Mass Media and Ideological Rivalries among Indonesian Muslims", Indonesia, no. 64, 1997, pp. 77-103 [http://dx.doi. org $/ 10.2307 / 3351436]$.

----, "Global Violence and Indonesian Muslim Politics", American Anthropologist, vol. 104, no. 3, 2002, pp. 754-65.

Herry Mohammad and Taufik Abriansyah, "Pesantren Eksekutif: Agar Tak Menohok Kawan”, Gatra, 1999.

Hikam, Muhammad A.S., Politik Kewarganegaraan: Landasan Redemokratisasi 
ICMI and Its Roles in the Development of the Middle Class Muslim

di Indonesia, Jakarta: Erlangga, 1999.

Jacques Bertrand, "False Starts, Succession Crises, and Regime Transition:

Flirting with Openness in Indonesia", Pacific Affairs, vol. 69, no. 3, 1996, pp. 319-340 [http://dx.doi.org/10.2307/2760922].

Juliantara, Dadang, "Kelas Menengah Muslim dalam Medan Perubahan:

Sebuah Catatan tentang ICMI", in ICMI Negara dan Demokrasi :

Catatan Kritis Kaum Muda, ed. by Zuli Qodir and Lalu M. Iqbal Songell, Yogyakarta: Kelompok Studi Lingkaran Pustaka Pelajar, 1995.

Legge, J.D., Sukarno: A Political Biography, Sydney: George Allen \& Unwin, 1985.

Liddle, R. William, "The Islamic Turn in Indonesia: A Political Explanation", The Journal of Asian Studies, vol. 55, no. 3, 1996, pp. 613-34 [http://dx.doi.org/10.2307/2646448].

MacIntyre, Andrew, "Indonesia in 1993: Increasing Political Movement?", Asian Survey, vol. 34, no. 2, 1994, pp. 111-118 [http://dx.doi. org $/ 10.2307 / 2645110]$.

Makka, A. Makmur and Dhurorudin Mashad, ICMI: Dinamika Politik Islam di Indonesia, Jakarta: Pustaka CIDESINDO, 1997.

Mallarangeng, Rizal and R. William Liddle, "Indonesia in 1995: The Struggle for Power and Policy", Asian Survey, vol. 36, no. 2, 1996, pp. 109-116 [http://dx.doi.org/10.2307/2645806].

Mariappan, Kntayya, Ketidaksamaan Sosial, Kuala Lumpur: Utusan Publications, 2000.

McKendrick, David, "Indonesia in 1991: Growth, Privilege, and Rules", Asian Survey, vol. 32, no. 2, 1992, pp. 103-110 [http://dx.doi. org $/ 10.2307 / 2645206]$.

Mujani, Saiful, "Kultur Kelas Menengah dan Kelahiran ICMI”, Studia Islamika, vol. 1, no. 1, 1994 [http://dx.doi.org/10.15408/sdi. v1i1.872].

----, "Mitos Politik Aliran dan Aspirasi Politik ICMI Modernis", Studia Islamika, vol. 2, no. 1, 1995, pp. 209-42 [http://dx.doi.org/10.15408/ sdi.v2i1.847].

Rahardjo, M. Dawam, Intelektual Intelegensia dan Perilaku Politik Bangsa: 
Risalah Cendekiawan Muslim, Bandung: Penerbit Mizan, 1993.

----, Masyarakat Madani: Agama, Kelas Menengah, dan Perubahan Sosial, Jakarta: LP3ES-LSAF, 1999.

Ramage, Douglas E., Percaturan Politik di Indonesia: Demokrasi, Islam, dan Ideologi Toleransi, trans. by Hartono Hadikusumo, Yogyakarta: Matabangsa, 2002.

Ramelan, Mariana, “Tahajudku Cuma Untuk Keluarga”, Ummat, vol. 1, no. 16, 1996.

Risnayanti, Besse and Hafied Cangara, "Jilbab Sebagai Simbol Komunikasi di Kalangan Mahasiswa Universitas Hasanuddin: Studi Komunikasi Nonverbal", KAREBA : Jurnal Ilmu Komunikasi, vol. 1, no. 2, 2016, pp. 149-76 [http://dx.doi.org/10.31947/kjik.v1i2.305].

"Scripturalism Media Dakwah: Satu Bentuk Pemikiran dan Aksi Politik Islam Masa Orde Baru”, Ulumul Qur'an, vol. 4, no. 3, 1993, pp. 53-65.

Sholahuddin, Afif, Membangun Centrum Gerakan di Era Liberalisasi., Jakarta: PB PMII, 2004.

Sumarsono, Tatang, Sajadah Panjang Bimbo: 30 Tabun Perjalanan Kelompok Musik Religius, Jakarta: Mizan, 1998.

Suryadinata, Leo, "Democratization and Political Succession in Suharto's Indonesia", Asian Survey, vol. 37, no. 3, 1997, pp. 269-280 [http:// dx.doi.org/10.2307/2645663].

Tanthowi, Pramono U., Kebangkitan Politik Kaum Santri: Islam dan Demokratisasi di Indonesia 1990-2000, Jakarta: Pusat Studi Agama dan Peradaban, 2005.

Vatikiotis, Michael R.J., Political Change in Southeast Asia: Trimming the Banyan Tree, London and New York: Routledge, 1996.

Yaakub, Noran Fauziah, Pengantar Sosiologi, Petaling Jaya: Penerbit Fajar Bakti Sdn Bhd, 1987. 